\title{
Phytophthora pathogens threaten rare habitats and conservation plantings
}

\author{
Susan J. Frankel', Janice Alexander², Diana Benner ${ }^{3}$, Janell Hillman ${ }^{4}$ \& \\ Alisa Shor ${ }^{5}$
}

\begin{abstract}
Phytophthora pathogens are damaging native wildland vegetation including plants in restoration areas and botanic gardens. The infestations threaten some plants already designated as endangered and degrade high-value habitats. Pathogens are being introduced primarily via container plant nursery stock and, once established, they can spread to adjacent areas where plant species not previously exposed to pathogens may become infected. We review epidemics in California - caused by the sudden oak death pathogen Phytophthora ramorum Werres, De Cock \& Man in 't Veld and the first USA detections of $P$. tentaculata Kröber \& Marwitz, which occurred in native plant nurseries and restoration areas - as examples to illustrate these threats to conservation plantings.
\end{abstract}

\section{Introduction}

Phytophthora (order: Peronosporales; kingdom: Stramenopila) pathogens have increasingly been identified as associated with plant dieback and mortality in restoration areas (Bourret, 2018; Garbelotto et al., 2018; Sims et al., 2019), threatened and endangered species habitat (Swiecki et al., 2018a), botanic gardens and wildlands in coastal California (Cobb et al., 2017; Metz et al., 2017) and southern Oregon (Goheen et al., 2017). The pathways for Phytophthora and other pathogen introductions are not always known but often they arrive inadvertently on infested plants for planting (nursery stock) (Liebhold et al., 2012; Parke et al., 2014; Jung et al., 2015; Swiecki et al., 2018b; Sims et al., 2019). Once established, Phytophthora spp. have the potential to reduce growth, kill and cause other undesirable impacts on a wide variety of native or horticultural vegetation (Brasier et al., 2004; Hansen 2007, 2011; Scott \& Williams, 2014; Jung et al., 2018).

In this review, we focus on the consequences of two pathogen introductions: the sudden oak death pathogen Phytophthora ramorum Werres, De Cock \& Man in 't Veld, as it attacks new host species more than two decades after it was first discovered in California

\footnotetext{
${ }^{1}$ Susan J. Frankel is a Plant Pathologist with the USDA Forest Service.

Address: Pacific Southwest Research Station, 800 Buchanan Street, Albany, CA 94710, USA.

Email: susan.frankel@usda.gov

2 Janice Alexander is Outreach Specialist at University of California Cooperative Extension, Marin County.

Address: 1682 Novato Blvd \# 150B, Novato, CA 94947, USA.

${ }^{3}$ Diana Benner is owner of the Watershed Nursery.

Address: 601 A Canal Blvd, Richmond, CA 94804, USA.

${ }^{4}$ Janell Hillman is Senior Biologist/Plant Ecologist at Santa Clara Valley Water District.

Address: 5750 Almaden Expressway, San Jose, CA 95118, USA.

${ }^{5}$ Alisa Shor is Director of Park Nurseries, Golden Gate National Parks Conservancy.

Address: 201 Fort Mason, San Francisco, CA 94123, USA.
} 
(Rooney-Latham et al., 2017), and the first detections in the USA of $P$. tentaculata Kröber \& Marwitz, which occurred in California native plant nurseries and restoration plantings from 2012 to 2014 (Rooney-Latham et al., 2015; Sims et al., 2018).

Follow-up investigations of these epidemics revealed that Phytophthora pathogens are common in ornamental nurseries (Yakabe et al., 2009; Parke et al., 2014; Knaus et al., 2015; Blomquist et al., 2016) and, in California, native plant nurseries and are being introduced to new areas when outplanted (Sims et al., 2018; RooneyLatham et al., 2019; Swiecki et al., 2019). Once established, Phytophthora pathogens may infest the site and often are very difficult to eradicate or curtail (Goheen et al., 2017; Valachovic et al., 2017).

We focus on invasions into conservation or mitigation plantings, such as rare plant habitats, botanic gardens or restoration areas. Since these plantings are designed to improve habitats, enhance biodiversity or expand plant populations with high conservation value, their failure degrades the natural resources that they aim to benefit. Taken together, these California plant pathogen introductions serve as evidence that without additional preventive measures to ensure nursery stock health, actions intended to sustain and protect species may be undermined. Efforts to retain remnant plant populations in botanic gardens or restoration areas can be destroyed if measures are not taken to ensure that plant pathogens are not introduced into rare habitats, or elsewhere, where they can eventually encroach into conservation plantings.

\section{Wildland and restoration} Phytophthora epidemics in California

The sudden oak death pathogen spreads from wildlands to rare plants

For more than 30 years, coastal California and Oregon landscapes have been under attack by the invasive sudden oak death pathogen, Phytophthora ramorum, where over 50 million trees have been killed, primarily Notholithocarpus densiflorus (Hook. \& Arn.) Manos, Cannon \& S.H. Oh (tanoak) and Quercus agrifolia Née (coast live oak) (Rizzo et al., 2005; Frankel, 2008; Garbelotto \& Hayden, 2012; California Oak Mortality Task Force (COMTF), 2018) (Fig. 1). The pathogen has been introduced several times, most likely on ornamental nursery stock; once established, it spread via windblown rain into adjacent forests, parks and gardens (Grünwald et al., 2008; Grünwald et al., 2012). Unexpectedly, starting in 2015 after two decades of monitoring, several more plant species, including Chrysolepis chrysophylla (Douglas ex Hook.) Hjelmqvist (chinquapin), Pickeringia montana Nutt. ex Torr. \& A. Gray (chaparral pea) and rare Arctostaphylos spp. Adans. (manzanitas) were recognised as hosts showing symptoms of dieback and mortality (COMTF, 2017; Rooney-Latham et al., 2017). Many of these plant hosts are endangered (US Fish and Wildlife Service, 1998) or threatened species (Calflora, 2019) and several of the invasions occurred in botanic garden collections. These detections demonstrate the detrimental effects that invasive pathogens can have on plant life. $P$. ramorum is known to infect over 100 plant species including hardwoods, conifers, shrubs, herbaceous plants and ferns (US Department of Agriculture, 2013). Its broad 
host range includes common plants, such as tanoak (Bowcutt, 2015), and, over time, rare plants in conservation plantings and remnant habitats have been found as symptomatic and infected, apparently exposed to inoculum from nearby infested forests (Davidson et al., 2005; Hansen et al., 2008).

From 2015 to 2017, Phytophthora ramorum was first recognised on several rare, threatened or endangered manzanita species in wildlands and botanic gardens (Table 1). In maritime chaparral of Marin and San Mateo Counties infection was observed on Arctostaphylos glandulosa Eastw. (Eastwood manzanita), A. virgata Eastw. (Marin manzanita) (Rooney-Latham et al., 2017) and A. montaraensis Roof (Montara manzanita) (Matteo Garbelotto, University of California, Berkeley, pers. comm.). Additionally, the pathogen infested plants in two botanic gardens. In the University of California, Santa Cruz Arboretum and Botanic Garden (Santa Cruz County), P. ramorum was detected on A. hooveri P.V. Wells (Hoover's manzanita), A. montereyensis Hoover (Toro manzanita), A. morroensis Wiesl. \& Schreiber (Morro manzanita), A. pilosula Jeps. \& Wiesl. (La Panza manzanita), A. pumila Nutt. (dune manzanita) and $A$. silvicola Jeps. (Bonny Doon manzanita) (Matteo Garbelotto, pers. comm.). The pathogen was also reported on multiple rare manzanita species at the East Bay Regional Park Botanic Garden in Tilden Park near Berkeley, CA (Alameda County) - further details will be published soon by the California Department of Food and Agriculture (Suzanne Rooney-Latham, CDFA, pers. comm.). Symptoms appeared as leaf spots, dieback or complete plant mortality. All the detections occurred in areas known to be infested with $P$. ramorum for several decades, but symptoms on manzanita species had not previously been reported.

Also on East Bay Regional Park District (EBRPD) lands, Phytophthora ramorum was found damaging Arctostaphylos pallida Eastw. (pallid manzanita), a state endangered plant. State law requires the EBRPD protect

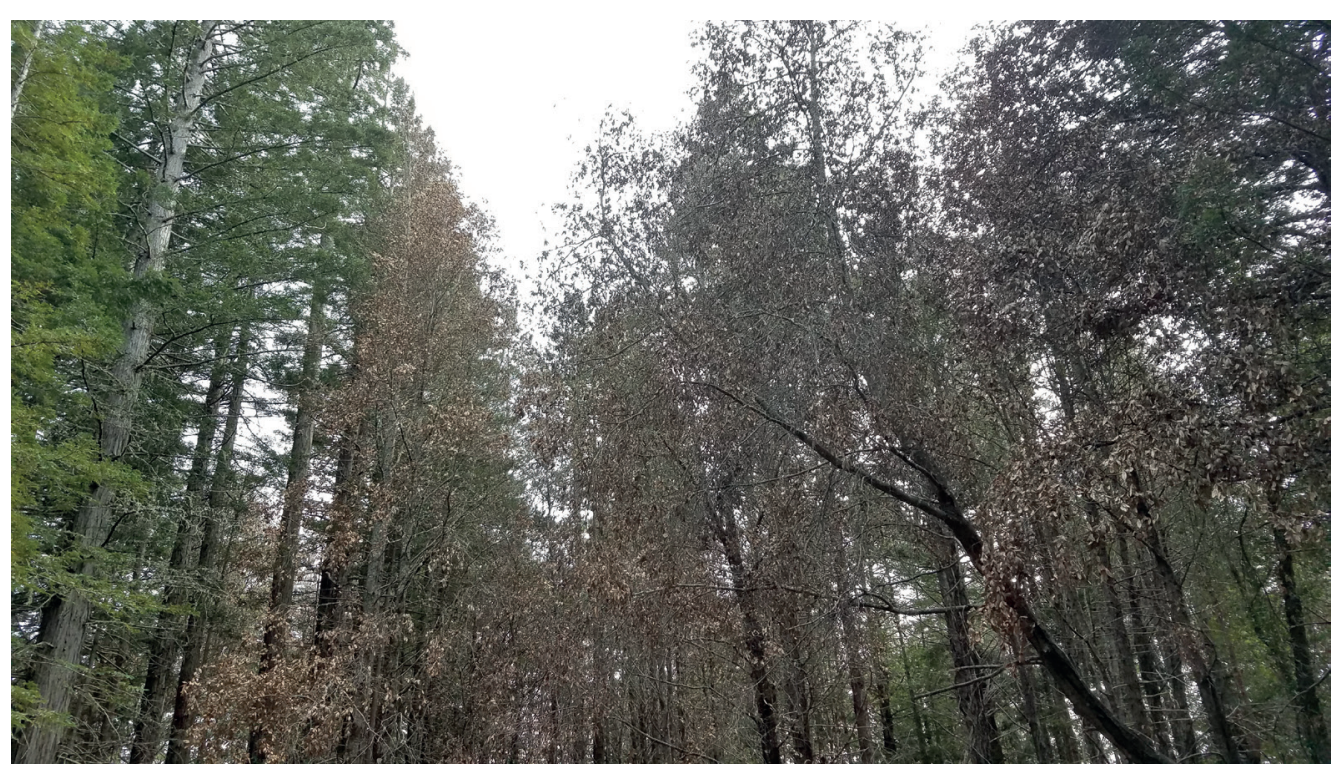

Fig. 1 Sudden oak death of tanoak in Sonoma County, CA. Photo: Christopher Lee, California Department of Forestry and Fire Protection. 


\begin{tabular}{|l|l|l|}
\hline Scientific name & Location, Year & Reference \\
\hline $\begin{array}{l}\text { Arctostaphylos } \\
\text { glandulosa }\end{array}$ & Wildland, Marin Co., 2015 & Rooney-Latham et al., 2017 \\
\hline $\begin{array}{l}\text { Arctostaphylos } \\
\text { hooveri }\end{array}$ & $\begin{array}{l}\text { Botanic Garden, Santa Cruz Co., } \\
2017\end{array}$ & $\begin{array}{l}\text { Matteo Garbelotto, University of } \\
\text { California, Berkeley, pers. comm. }\end{array}$ \\
\hline $\begin{array}{l}\text { Arctostaphylos } \\
\text { montaraensis }\end{array}$ & Wildland, San Mateo Co., 2017 & $\begin{array}{l}\text { Matteo Garbelotto, University of } \\
\text { California, Berkeley, pers. comm. } \\
\text { Discovered in 2017 SOD Blitz survey. }\end{array}$ \\
\hline $\begin{array}{l}\text { Arctostaphylos } \\
\text { montereyensis }\end{array}$ & Botanic Garden, Santa Cruz Co., & $\begin{array}{l}\text { Matteo Garbelotto, University of } \\
\text { California, Berkeley, pers. comm. }\end{array}$ \\
\hline $\begin{array}{l}\text { Arctostaphylos } \\
\text { morroensis }\end{array}$ & $\begin{array}{l}\text { Botanic Garden, Santa Cruz Co., } \\
2017\end{array}$ & $\begin{array}{l}\text { Matteo Garbelotto, University of } \\
\text { California, Berkeley, pers. comm. }\end{array}$ \\
\hline $\begin{array}{l}\text { Arctostaphylos } \\
\text { pallida }\end{array}$ & Wildland, Alameda Co., 2017 & Swiecki et al., 2018a \\
\hline $\begin{array}{l}\text { Arctostaphylos } \\
\text { pilosula }\end{array}$ & $\begin{array}{l}\text { Botanic Garden, Santa Cruz Co., } \\
2017\end{array}$ & $\begin{array}{l}\text { Matteo Garbelotto, University of } \\
\text { California, Berkeley, pers. comm. }\end{array}$ \\
\hline $\begin{array}{l}\text { Arctostaphylos } \\
\text { pumila }\end{array}$ & $\begin{array}{l}\text { Botanic Garden, Santa Cruz Co., } \\
2017\end{array}$ & $\begin{array}{l}\text { Matteo Garbelotto, University of } \\
\text { California, Berkeley, pers. comm. }\end{array}$ \\
\hline $\begin{array}{l}\text { Arctostaphylos } \\
\text { silvicola }\end{array}$ & $\begin{array}{l}\text { Botanic Garden, Santa Cruz Co., } \\
2017\end{array}$ & $\begin{array}{l}\text { Matteo Garbelotto, University of } \\
\text { California, Berkeley, pers. comm. }\end{array}$ \\
\hline $\begin{array}{l}\text { Arctostaphylos } \\
\text { virgata }\end{array}$ & Wildland, Marin Co., 2015 & Rooney-Latham et al., 2017 \\
\hline
\end{tabular}

Table 1 Partial list of Arctostaphylos spp. (manzanitas) showing symptoms of $P$. ramorum infection discovered in California since 2015. All the plants developed symptoms in natural conditions.

A. pallida populations while the EBRPD manages this maritime chaparral habitat in the wildland-urban interface for plant health and fire fuels management. In response, botanists and plant pathologists have inventoried the populations, surveyed for pathogens, removed invasive weeds and deposited seed of pallid manzanita in several banks (EBRPD, 2017; Hammond, 2018).

Oregon's Phytophthora ramorum infestation demonstrates how difficult this pathogen is to control in forests and that introductions on nursery plants continue despite quarantines. In Oregon, P. ramorum was first discovered in coastal south-west Oregon forests in Curry County in July 2001 (Goheen et al., 2002) and subsequently introduced again in 2008 and 2014 (Grünwald et al., 2016; Goheen et al., 2017). An interagency team conducted early detection monitoring and mandatory eradication from 2001 to 2012, which slowed but did not stop pathogen spread and intensification (Peterson et al., 2015). As required by state regulations, infested trees and other host plants were cut and burned along with a buffer of adjacent vegetation (Goheen et al., 2017). From 2009 to 2011, funding limitations resulted in a treatment backlog of many infestations near the centre of the quarantine area (Kanaskie et al., 2017), which led to creation of a Generally Infested Area (GIA) in which eradication was no longer required by law (Kanaskie \& Navarro, 2019). In the 
absence of eradication treatments within the GIA, tanoak mortality increased rapidly (Fig. 2). Oregon Department of Forestry reports that on ten 1-ha plots near Brookings, Oregon (Curry County), overstorey tanoak mortality increased from less than 5 per cent to an average of 87 per cent over a four-year period. Also from 2012 through 2017 the disease spread rapidly, and the untreated, infested area within the 151 sq. km GIA increased from 85 ha to more than 1,020 ha (Kanaskie \& Navarro, 2019).

The threat of new Phytophthora ramorum infestations from nursery stock movement was demonstrated yet again in Oregon in 2015, where despite federal (7 CFR 301.92, US Department of Agriculture, 2002) and state (603-052-1230 and 603-052-1250, Oregon
Department of Agriculture, 2001) quarantines, another, more aggressive lineage of the pathogen, the European Union 1 (EU1) clonal lineage, was detected as introduced for the first time into a USA forest, on tanoak located approximately $1.6 \mathrm{~km}$ from a small private nursery near the Pistol River (Curry County, Oregon) (Grünwald et al., 2016; Grünwald et al., 2019). The EU1 clonal lineage was also found in the nursery (Grünwald et al., 2016). State-mandated eradication has been conducted on over 190 ha that harboured the EU1 lineage of $P$. ramorum, but the pathogen continues to spread (Navarro et al., 2019).

The Sudden Oak Death: Economic Assessment, conducted for the Oregon Department of Forestry concluded that if the current sudden oak death treatment regime

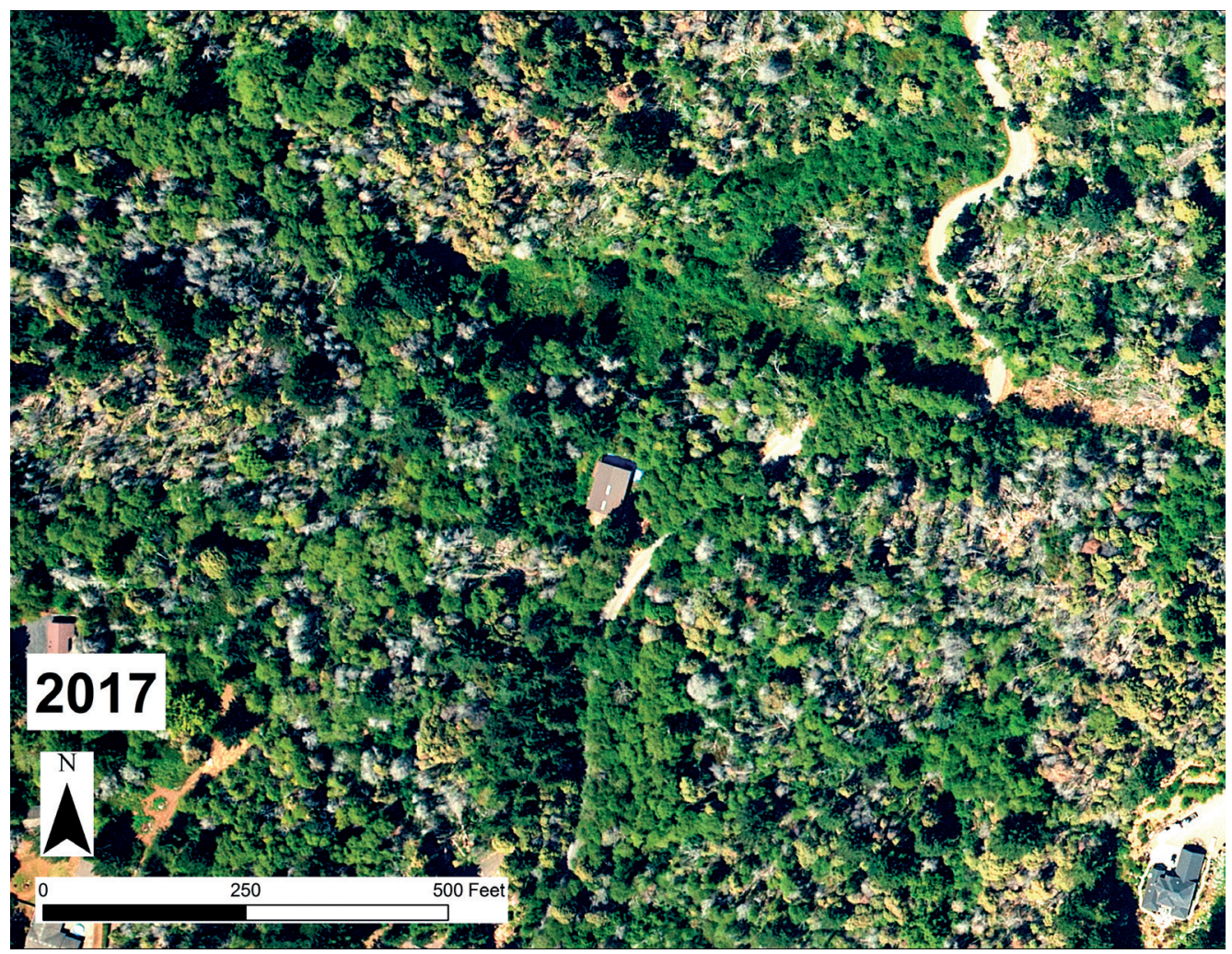

Fig. 2 Aerial view of mortality of dominant and co-dominant tanoaks killed by Phytophthora ramorum inside the Generally Infested Area near Brookings, OR. Photo: Oregon Department of Forestry. 
(clear-cutting of infestations on the leading edge of disease expansion) was terminated, serious economic impacts might occur as Phytophthora ramorum moved north into Coos County (Highland Economics et al., 2019). Projected impacts included quarantines on south-west Oregon timber exports by China, Japan and Korea resulting in a loss of 1,200 jobs related to timber export, equal to $\$ 57.9$ million in annual wages, as well as other losses in revenue from depressed property values and a decrease in tourism. The assessment also states that $P$. ramorum strikes at core values that elude economic

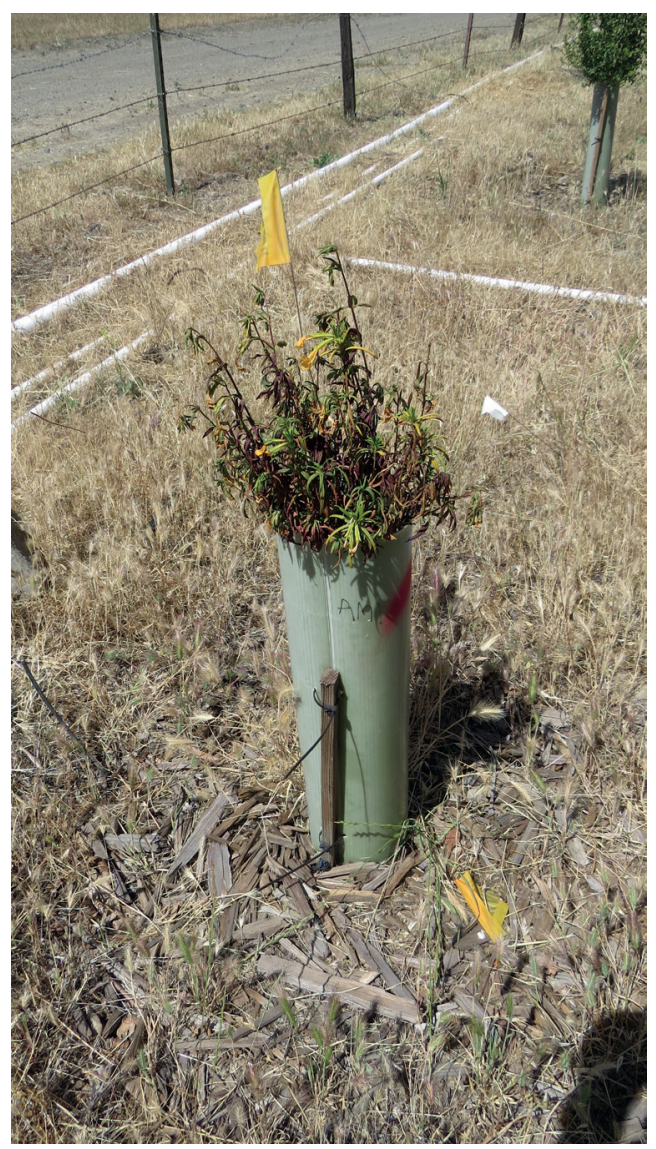

Fig. 3 Phytophthora tentaculata infected Diplacus aurantiacus (sticky monkey flower) in a restoration planting in Alameda County, CA, in 2014. Photo: Tedmund Swiecki, Phytosphere Research. quantification, particularly tribal cultural values (Highland Economics et al., 2019).

\section{Phytophthora tentaculata and other Phytophthora detections in California restoration areas and native plant nurseries}

Over the past five years, Phytophthora species have been introduced into restoration areas due to outplanting of infested nursery container plants (Garbelotto et al., 2018; Swiecki et al., 2018a, b; 2019). In 2012, P. tentaculata was discovered causing severe root and crown rot on Diplacus aurantiacus Jeps. (sticky monkey flower) at a native plant nursery in Monterey County and noted as a first USA detection (Rooney-Latham \& Blomquist, 2014). In 2014, the pathogen was detected in five California native plant nurseries (Butte, Monterey, Placer, Santa Cruz Counties) and three habitat restoration sites in Monterey and Alameda Counties (Frankel et al., 2015) (Fig. 3). These detections shocked plant ecologists, as well as native plant growers, as evidence emerged that $P$. tentaculata had been unintentionally but extensively introduced into habitat restoration sites in the greater San Francisco Bay Area (Frankel et al., 2018; Garbelotto et al., 2018).

Several habitat restoration sites designed to serve as mitigation for municipal water infrastructure projects were inadvertently planted with Phytophthora tentaculata infected plants including Frangula californica (Eschsch.) A. Gray (coffeeberry), Heteromeles arbutifolia (Lindl.) M. Roem. (toyon) and others (Fig. 4). The plantings extended along several kilometres of riparian area at various locations in Alameda County (Lyman et al., 2017) (Fig. 4). In another first detection in the USA, P. quercina was found on a planted Quercus lobata Née (valley oak) in a restoration area in San Jose (Santa Clara 


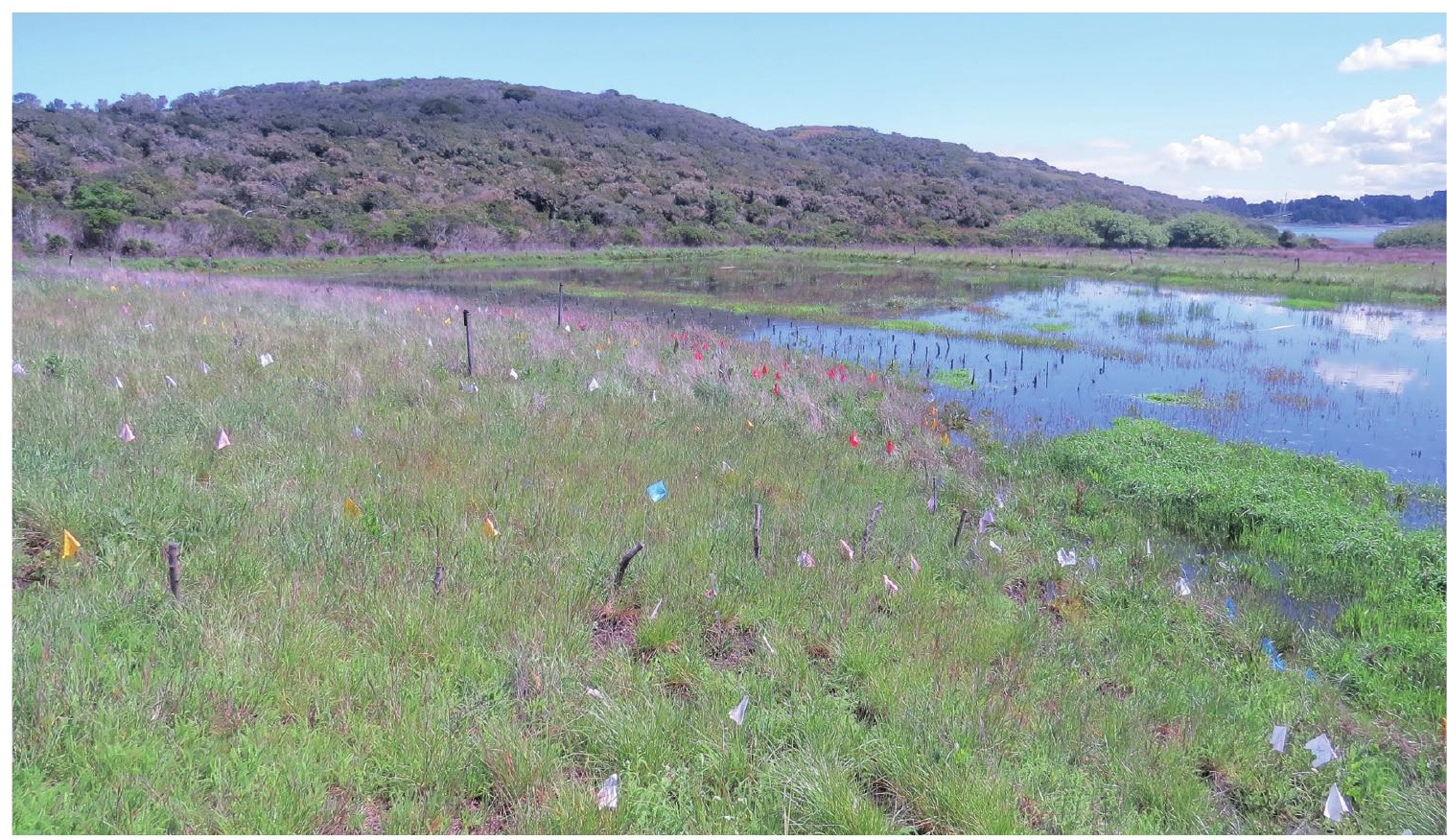

Fig. 4 Alameda County restoration site showing coloured flags noting locations of outplanted container nursery stock. Post-planting, the site tested positive for Phytophthora. Photo: Tedmund Swiecki, Phytosphere Research.

County) (Swiecki et al., 2018a). In 2009, both $P$. quercina and $P$. tentaculata were listed among the top five most threatening Phytophthora species, not yet detected in the USA, in an USDA Animal and Plant Health Inspection Service (APHIS) pest risk analysis (Schwartzburg et al., 2009), so plant ecologists were challenged with developing a means to contain these infestations.

In response to these soil-borne Phytophthora introductions, project managers suspended plantings, cancelled orders of nursery stock and invested millions of dollars in solarisation treatments to clean up contaminated sites. But such measures achieved only partial eradication (Hillman et al., 2017; Lyman et al., 2017). The California native plant nursery industry responded by voluntarily submitting samples to the California Department of Food and
Agriculture diagnostic lab for Phytophthora testing. Phytophthora was confirmed from over three quarters ( 77 per cent) of the 26 participating nurseries, on 37 per cent of the 402 samples tested from plants in 22 host families (Rooney-Latham et al., 2019). Rooney-Latham et al. (2019) conclude that their findings "document the widespread occurrence of Phytophthora spp. in native plant nurseries and highlight the potential risks associated with outplanting infested nursery-grown stock into residential gardens and wildlands".

In 2015, recognising that neither discontinuation of restoration planting nor a switch to direct seeding represent an ideal long-term approach to Phytophthora prevention, we created the Phytophthoras in Native Habitats Work Group (the Work Group) ${ }^{6}$ to develop best management 
practices and other recommendations to prevent further pathogen introductions and ensure that the benefits of restoration are not foregone or significantly delayed due to plant health risks.

The Work Group utilises an interdisciplinary, collaborative approach to bring together native plant growers, vegetation managers, restoration design and installation contractors, regulators and plant pathologists to address the potential for pathogen introduction in all phases of restoration from design to planting and site maintenance. The Work Group is currently conducting a pilot project, entitled "Accreditation to Improve Restoration and Native Plant Nursery Stock Cleanliness" (AIR), to promote sanitation and other preventive measures in restoration nurseries (Frankel et al., 2019; Swiecki et al., 2019). Eleven California nurseries have voluntarily enrolled and committed to a self-assessment followed by an external audit to confirm that they are producing plants with the practices outlined by the Work Group (2016) best management practices for restoration nursery stock. These practices require growers to dedicate a significant amount of time and attention to phytosanitation throughout their operations. The nursery assessment covers all aspects of nursery production, divided into 12 categories including layout, water source, media, propagation and sanitation practices.

To date, four nurseries have completed all the requirements and have been deemed "AIR compliant", valid for one year. However, in one of the participating nurseries in Sonoma County, as part of the voluntary inspection, auditors detected Phytophthora pseudocryptogea Safaief., Mostowf., G.E. Hardy $\&$ T.I. Burgess infection on an endangered species, Oenothera deltoides Torr. \& Frém. ssp. howellii (Munz) W. Klein (Antioch Dunes evening primrose). The nursery is working to improve production practices to prevent future pathogen introductions. The virulence of P. pseudocryptogea on native plants is not fully known but it has been detected on Arctostaphylos hookeri G. Don ssp. ravenii P.V. Wells (Raven's manzanita) on federally managed lands of the Presidio (San Francisco, (A). Raven's manzanita is an endangered species; in the mid-1980s only one single plant existed (Rolston, 1985; Holloran, 1996). The plant has been cloned but some of the clones are suffering significant dieback due to Phytophthora infection as well as other pest problems (National Park Service, undated).

\section{Conclusions}

Examining the consequences of these plant pathogen epidemics demonstrates the importance of prevention to avert pathogen introductions to sustain and protect rare plants and habitats. Once introduced into landscapes, these pathogens are very difficult to impossible to control (Kanaskie \& Navarro, 2019) and may cause damage to many high-value plants (Garbelotto et al., 2018). When environmental conditions are favourable, pathogens may spread through soil or water movement or via windblown rain and colonise numerous plant species (Eyre et al., 2013).

Nurseries are widely distributed throughout the US (Reichard et al., 2001) and their irrigated conditions are conducive to Phytophthora development (Swiecki et al., 2018b). Nursery production poses a risk for pathogen development and spread within and beyond their facilities via contaminated run-off or outplanted stock (Pérez-Sierra \& Jung, 2013; Simamora et al., 2018; Weiland et al., 2018). Best management practices that emphasise strict phytosanitation can prevent pathogen development in nurseries (Sims et 
al., 2019), and thereby protect adjacent and distant natural areas.

Climate change and human population pressure are increasing the desire and need to restore at-risk and degraded ecosystems (Seddon et al., 2014). Restoration plantings provide opportunities to reverse damage due to development, desertification or pollution as they slow biodiversity loss and enhance urban and wildland environments (Perring et al., 2015). Due to environmental changes that limit plant species survival, restoration or conservation plantings may be the only way some species can grow and survive (Mounce et al., 2017). However, introduced plant pathogens may impair efforts to conserve plant diversity as they can persist in the soil, making it unsuitable for plants (Swiecki et al., 2018a). Prevention of invasive species introductions in all types of landscaping and restoration, whatever the scale, is an important part of protecting native habitats (Simamora et al., 2018).

\section{References}

BLOMQUIST, C.L., YAKABE, L.E., ROONEYLATHAM, S., MCROBERTS, N. \& THOMAS, C. (2016). Detection of Phytophthora ramorum in nurseries and forest lands in California in 2004 to 2009. Plant Disease, 100(1): 139-148.

BOURRET, T.B. (2018). Efforts to detect exotic Phytophthora species reveal unexpected diversity. PhD dissertation. University of California, Davis.

BOWCUTT, F. (2015). The Tanoak Tree: An Environmental History of a Pacific Coast Hardwood. University of Washington Press, Seattle, WA.

BRASIER, C.M., KIRK, S., DELCAN, J., COOKE, D.E., JUNG, T. \& MAN IN 'T VELD, W.A. (2004). Phytophthora alni sp. nov. and its variants: designation of emerging heteroploid hybrid pathogens spreading on Alnus trees. Mycological Research, 108(10): 1172-1184.

CALFLORA (WEB APPLICATION) (2019). Berkeley,
CA. Available online: https://www.calflora.org/ (accessed August 2019).

\section{CALIFORNIA OAK MORTALITY TASK}

FORCE (2017). November newsletter.

Available online: www.suddenoakdeath.org/ wp-content/uploads/2017/11/COMTF-ReportNovember-2017-4.pdf (accessed April 2019).

\section{CALIFORNIA OAK MORTALITY TASK FORCE} (2018). November newsletter. Available online: www.suddenoakdeath.org/wp-content/ uploads/2018/11/COMTF-Report-Nov-2018.pdf (accessed April 2019).

COBB, R., HARTSOUGH, P., ROSS, N., KLEIN, J., LAFEVER, D., FRANKEL, S. \& RIZZO, D. (2017). Resiliency or restoration: management of sudden oak death before and after outbreak. Forest Phytophthoras, 7(1): 1-14.

DAVIDSON, J.M., WICKLAND, A.C., PATTERSON, H.A., FALK, K.R. \& RIZZO, D.M. (2005).

Transmission of Phytophthora ramorum in mixedevergreen forest in California. Phytopathology, 95(5): 587-596.

EAST BAY REGIONAL PARK DISTRICT (2017). Pallid manzanita management plan, May 2017.

EYRE, C.A., KOZANITAS, M. \& GARBELOTTO, M. (2013). Population dynamics of aerial and terrestrial populations of Phytophthora ramorum in a California forest under different climatic conditions. Phytopathology, 103(11): 1141-1152.

FRANKEL, S.J. (2008). Sudden oak death and Phytophthora ramorum in the USA: a management challenge. Australasian Plant Pathology, 37(1): 19-25.

FRANKEL, S.J., ALEXANDER, J., BENNER, D. \& SHOR, A. (2018). Coordinated response to inadvertent introduction of pathogens to California restoration areas. California Agriculture, 72(4): 205-207.

FRANKEL, S.J., SWIECKI, T.J., BERNHARDT, E.A., BENNER, D., BLOMQUIST, C. \& ROONEY-LATHAM, S. (2019). Accreditation to improve restoration program shows promise for pathogen prevention. Abstract. Seventh Sudden Oak Death Science and Management Symposium, 25-27 June 2019, San Francisco, CA.

FRANKEL, S.J., SWIECKI, T.J., BERNHARDT, E.A., BLOMQUIST, C. \& ROONEY-LATHAM, S. (2015). Pest Alert, Phytophthora tentaculata. USDA Forest 
Service, Pacific Southwest Research Station. Available online: http://www.suddenoakdeath.org/ wp-content/uploads/2015/02/P.tentaculata.Pest_. Alert_.022315.pdf (accessed April 2019).

GARBELOTTO, M., FRANKEL, S.J. \& SCANU, B. (2018). Soil- and waterborne Phytophthora species linked to recent outbreaks in northern California restoration sites. California Agriculture, 72(4): 208-216.

GARBELOTTO, M. \& HAYDEN, K.J. (2012). Sudden oak death: interactions of the exotic oomycete Phytophthora ramorum with naïve North American hosts. Eukaryotic Cell, 11(11): 1313-1323.

GOHEEN, E.M., HANSEN, E.M., KANASKIE, A., MCWILLIAMS, M.G., OSTERBAUER, N. \& SUTTON, W. (2002). Sudden oak death caused by Phytophthora ramorum in Oregon. Plant Disease, 86(4): 441.

GOHEEN, E.M., KANASKIE, A., NAVARRO, S. \& HANSEN, E. (2017). Sudden oak death management in Oregon tanoak forests. Forest Phytophthoras, 7(1): 45-53.

GRÜNWALD, N.J., GARBELOTTO, M., GOSS, E.M., HEUNGENS, K. \& PROSPERO, S. (2012). Emergence of the sudden oak death pathogen Phytophthora ramorum. Trends in Microbiology, 20(3): 131-138.

GRÜNWALD, N.J., GOSS, E.M. \& PRESS, C.M. (2008). Phytophthora ramorum: a pathogen with a remarkably wide host range causing sudden oak death on oaks and ramorum blight on woody ornamentals. Molecular Plant Pathology, 9(6): 729-740.

GRÜNWALD, N.J., LARSEN, M.M., KAMVAR, Z.N., REESER, P.W., KANASKIE, A., LAINE, J. \& WIESE, R. (2016). First report of the EU1 clonal lineage of Phytophthora ramorum on tanoak in an Oregon forest. Plant Disease, 100(5): 1024.

GRÜNWALD, N.J., LEBOLDUS, J.M. \& HAMELIN, R.C. (2019). Ecology and evolution of the sudden oak death pathogen Phytophthora ramorum. Annual Review of Phytopathology, 57. Review in Advance. Available online: https://doi.org/10.1146/ annurev-phyto-082718-100117 (accessed August 2019).

HAMMOND, M. (2018). Phytophthora impacts to endangered pallid manzanita in the East Bay Regional Park District. Abstract. 2018 California
Invasive Plant Council Symposium, 7-10 November, 2018, Monterey, CA.

HANSEN, E.M. (2007). Alien forest pathogens: Phytophthora species are changing world forests. Boreal Environment Research, 13: 33-41.

HANSEN, E.M. (2011). Phytophthora lateralis. Forest Phytophthoras 1(1). Available online: http:// journals.oregondigital.org/ForestPhytophthora/ article/view/1816 (accessed April 2019).

HANSEN, E.M., KANASKIE, A., PROSPERO, S., MCWILLIAMS, M., GOHEEN, E.M., OSTERBAUER, N., REESER, P. \& SUTTON, W. (2008).

Epidemiology of Phytophthora ramorum in Oregon tanoak forests. Canadian Journal of Forest Research, 38(5): 1133-1143.

\section{HIGHLAND ECONOMICS, MASON, BRUCE \&}

GIRARD (2019). Sudden oak death: economic impact assessment. Prepared for the Oregon Department of Forestry. Salem, OR. Available online: https://www.oregon.gov/ODF/Documents/ ForestBenefits/sudden-oak-death-economicimpact-assessment.pdf (accessed April 2019).

HILLMAN, J., SWIECKI, T.J., BERNHARDT, E.A., MEHL, H.K., BOURRET, T.B. \& RIZZO, D. (2017). 31 flavors to 50 shades of grey: Battling Phytophthoras in native habitats managed by the Santa Clara Valley Water District. In: FRANKEL, S.J. \& HARRELL, K.M. (tech. coords), Proceedings of the Sudden Oak Death Sixth Science Symposium. Gen. Tech. Rep. GTR-PSW-255. Albany, CA: U.S. Department of Agriculture, Forest Service, Pacific Southwest Research Station, p. 57.

HOLLORAN, P. (1996). The greening of the Golden Gate: community-based restoration at the Presidio of San Francisco. Restoration \& Management Notes, 14(2): 112-123.

JUNG, T., ORLIKOWSKI, L., HENRICOT, B., ABAD-CAMPOS, P., ADAY, A.G., AGUÍN CASAL, O., BAKONYI, J., CACCIOLA, S.O., CECH, T., CHAVARRIAGA, D., CORCOBADO, T., CRAVADOR,

A. ET AL. (2016). Widespread Phytophthora infestations in European nurseries put forest, semi-natural and horticultural ecosystems at high risk of Phytophthora diseases. Forest Pathology, 46: 134-163.

JUNG, T., PÉREZ-SIERRA, A., DURÁN, A., HORTA, M.J., BALCI, Y. \& SCANU, B. (2018). Canker and decline diseases caused by soil- and airborne Phytophthora species in forests and woodlands. 
Persoonia: Molecular Phylogeny and Evolution of Fungi, 40: 182-220.

KANASKIE, A. \& NAVARRO, S. (2019). Intensification of sudden oak death in Oregon forests in the absence of eradication treatments. Abstract. Seventh Sudden Oak Death Science and Management Symposium, 25-27 June 2019, San Francisco, CA.

KANASKIE, A., WIESE, R., NORLANDER, D., LAINE, J., NAVARRO, S., GOHEEN, E.M., RHATIGAN, R., HANSEN, E., SUTTON, W., REESER, P., GRÜNWALD, N., KAMVAR, Z. \& OSTERBAUER, N. (2017). Slowing spread of sudden oak death in Oregon forests, 2001-2015. In: FRANKEL, S.J. \& HARRELL, K.M. (tech. coords), Proceedings of the Sudden Oak Death Sixth Science Symposium. Gen. Tech. Rep. GTR-PSW-255. Albany, CA: US Department of Agriculture, Forest Service, Pacific Southwest Research Station, p. 1.

KNAUS, B.J., FIELAND, V.J., GRAHAM, K.A. \& GRÜNWALD, N.J. (2015). Diversity of foliar Phytophthora species on Rhododendron in Oregon nurseries. Plant Disease, 99(10): 1326-1332.

LIEBHOLD, A.M., BROCKERHOFF, E.G., GARRETT, L.J., PARKE, J.L. \& BRITTON, K.O. (2012). Live plant imports: the major pathway for forest insect and pathogen invasions of the US. Frontiers in Ecology and the Environment, 10: 135-143.

LYMAN, G., APPEL, J., INGOLIA, M., NATESAN, E. \& ORTIZ, J. (2017). Steam, solarization, and tons of prevention: The San Francisco Public Utilities Commission's fight to contain Phytophthoras in San Francisco Bay Area restoration sites. In: FRANKEL, S.J. \& HARRELL, K.M. (tech. coords), Proceedings of the Sudden Oak Death Sixth Science Symposium. Gen. Tech. Rep. GTR-PSW-255. Albany, CA: U.S. Department of Agriculture, Forest Service, Pacific Southwest Research Station, p. 56.

MASCHERETTI, S., CROUCHER, P.J.P., VETTRAINO, A., PROSPERO, S. \& GARBELOTTO, M. (2008). Reconstruction of the sudden oak death epidemic in California through microsatellite analysis of the pathogen Phytophthora ramorum. Molecular Ecology, 17(11): 2755-2768.

METZ, M., VARNER, J.M., MEENTEMEYER, R., FRANGIOSO, K. \& RIZZO, D. (2017). Lessons from 15 years of monitoring sudden oak death and forest dynamics in California forests. In: FRANKEL, S.J. \& HARRELL, K.M. (tech. coords), Proceedings of the Sudden Oak Death Sixth Science Symposium. Gen. Tech. Rep. GTR-PSW-255. Albany, CA: US Department of Agriculture, Forest Service, Pacific Southwest Research Station, pp. 2-3.

MOUNCE, R., SMITH, P. \& BROCKINGTON, S. (2017). Ex situ conservation of plant diversity in the world's botanic gardens. Nature Plants, 3 : 795-802.

NATIONAL PARK SERVICE (undated). Raven's Manzanita. Available online: https://www.nps.gov/ prsf/learn/nature/ravens-manzanita.htm (accessed April 2019).

NAVARRO, S., WIESE, R., NICHOLS, C., NORLANDER, D., KANASKIE, K., GOHEEN, E.M., HANSEN, E., SUTTON, W., REESER, P., GRÜNWALD, N. \& LEBOLDUS, J. (2019). Slowing the spread of sudden oak death in Oregon forests, 2001-2018. Abstract. Seventh Sudden Oak Death Science and Management Symposium, 25-27 June 2019, San Francisco, CA.

OREGON DEPARTMENT OF AGRICULTURE (2001). Phytophthora ramorum quarantine, 603-052-1230; Phytophthora ramorum Regulated Area for Nursery Stock, 603-052-1250. Plant Health Quarantines and Control Area Orders. Available online: https://www. oregon.gov/ODA/programs/PlantHealth/Pages/ PlantHealthQuarantines.aspx (accessed April 2019).

PARKE, J.L., KNAUS, B.J., FIELAND, V.J., LEWIS, C. \& GRÜNWALD, N.J. (2014). Phytophthora community structure analyses in Oregon nurseries inform systems approaches to disease management. Phytopathology, 104: 1052-1062.

PÉREZ-SIERRA, A. \& JUNG, T. (2013).

Phytophthora in woody ornamental nurseries. In: LAMOUR, K. (ed.), Phytophthora: A Global Perspective. CABI, Plant Protection Series 2. CABI, London, pp. 166-177.

PERRING, M.P., STANDISH, R.J., PRICE, J.N., CRAIG, M.D., ERICKSON, T.E., RUTHROF, K.X., WHITELEY, A.S., VALENTINE, L.E. \& HOBBS, R.J. (2015). Advances in restoration ecology: rising to the challenges of the coming decades. Ecosphere, 6(8): 131.

PETERSON, E.K., HANSEN, E.M. \& KANASKIE, A. (2015). Temporal epidemiology of sudden oak death in Oregon. Phytopathology, 105(7): 937-946.

PHYTOPHTHORAS IN NATIVE HABITATS WORK GROUP (2016). Guidelines to minimize 
Phytophthora pathogens in restoration nurseries. Available online: http://www.suddenoakdeath.org/ wp-content/uploads/2016/04/Restoration.Nsy_. Guidelines.final_.092216.pdf (accessed April 2019).

REICHARD, S.H. \& WHITE, P. (2001). Horticulture as a pathway of invasive plant introductions in the United States: most invasive plants have been introduced for horticultural use by nurseries, botanical gardens, and individuals. BioScience, 51(2): 103-113.

RIZZO, D.M., GARBELOTTO, M. \& HANSEN, E.M. (2005). Phytophthora ramorum: integrative research and management of an emerging pathogen in California and Oregon forests. Annual Review of Phytopathology, 43: 309-335.

ROLSTON, H. (1985). Duties to endangered species. BioScience, 35(11): 718-726.

ROONEY-LATHAM, S. \& BLOMQUIST, C.L. (2014). First report of root and stem rot caused by Phytophthora tentaculata on Mimulus aurantiacus in North America. Plant Disease, 98(7): 996.

ROONEY-LATHAM, S., BLOMQUIST, C.L., KOSTA, K.L., GOU, Y.Y. \& WOODS, P.W. (2019). Phytophthora species are common on nursery stock grown for restoration and revegetation purposes in California. Plant Disease, 103(3): 448-455.

ROONEY-LATHAM, S., BLOMQUIST, C.L., SWIECKI, T., BERNHARDT, E. \& FRANKEL, S.J. (2015). First detection in the US: New plant pathogen, Phytophthora tentaculata, in native plant nurseries and restoration sites in California. Native Plants Journal, 16(1): 23-27.

ROONEY-LATHAM, S., BLOMQUIST, C.L., WILLIAMS, A., GUNNISON, E. \& PASTALKA, T. (2017). Identification of five new hosts of Phytophthora ramorum in an infested forest in California. In: FRANKEL, S.J. \& HARRELL, K.M. (tech. coords), Proceedings of the Sudden Oak Death Sixth Science Symposium. Gen. Tech. Rep. GTR-PSW-255. Albany, CA: US Department of Agriculture, Forest Service, Pacific Southwest Research Station, pp. 83-84.

SCHWARTZBURG, K., HARTZOG, H., LANDRY, C., ROGERS, J. \& RANDALL-SCHADEL, B. (2009). Prioritization of Phytophthora of concern to the United States. USDA APHIS PPQ CPHST PERAL, Raleigh, NC.

SCOTT, P. \& WILLIAMS, N. (2014). Phytophthora diseases in New Zealand forests. New Zealand Journal of Forestry, 59(2): 14-21.

SEDDON, P.J., GRIFFITHS, C.J., SOORAE, P.S. \& ARMSTRONG, D.P. (2014). Reversing defaunation: restoring species in a changing world. Science, 345(6195): 406-412.

SIMAMORA, A.V., PAAP, T., HOWARD, K., STUKELY, M.J., HARDY, G.E.S.J. \& BURGESS, T.I. (2018). Phytophthora contamination in a nursery and its potential dispersal into the natural environment. Plant Disease, 102(1): 132-139.

SIMS, L.L., CHEE, C., BOURRET, T., HUNTER, S. \& GARBELOTTO, M. (2019). Genetic and phenotypic variation of Phytophthora crassamura isolates from California nurseries and restoration sites. Fungal Biology, 123(2): 159-169.

SIMS, L.L. \& GARBELOTTO, M. (2018).

Susceptibility to the rare Phytophthora tentaculata and to the widespread Phytophthora cactorum is consistent with host ecology and history. Forest Pathology, 48(5): e12446.

SIMS, L., TJOSVOLD, S., CHAMBERS, D. \&

GARBELOTTO, M. (2019). Control of Phytophthora species in plant stock for habitat restoration through best management practices. Plant Pathology, 68(1): 196-204.

SWIECKI, T.J., BERNHARDT, E.A. \& FRANKEL, S.J. (2018a). Phytophthora root disease and the need for clean nursery stock in urban forests. Part 1. Phytophthora invasions in the urban forest and beyond. Western Arborist, 44(3): 54-60.

SWIECKI, T.J., BERNHARDT, E.A. \& FRANKEL, S.J. (2018b). Phytophthora root disease and the need for clean nursery stock in urban forests. Part 2. Phytophthora in nurseries. Western Arborist, 44(4): 38-45.

SWIECKI, T.J., BERNHARDT, E.A. \& FRANKEL, S.J. (2019). Phytophthora root disease and the need for clean nursery stock in urban forests: Part 3. Prevention and management. Western Arborist, 45(1): 40-50.

US DEPARTMENT OF AGRICULTURE (2002). Code of Federal Regulations 301.92 Title 7 - Restrictions on interstate movement. Domestic quarantine notices. Phytophthora ramorum. Available online: https://www.govinfo.gov/content/pkg/CFR-2018title7-vol5/xml/CFR-2018-title7-vol5-sec301-92.xml (accessed April 2019). 
US DEPARTMENT OF AGRICULTURE (2013). List of regulated hosts and plants associated with Phytophthora ramorum. US Department of Agriculture, Animal and Plant Health Inspection Service. August 2013. Available online: https:// www.aphis.usda.gov/plant_health/plant_pest_ info/pram/downloads/pdf_files/usdaprlist.pdf (accessed April 2019).

US FISH AND WILDLIFE SERVICE (1998).

Endangered and threatened wildlife and plants: Determination of threatened status for one plant, Arctostaphylos pallida (Pallid Manzanita), From the Northern Diablo Range of California. Federal Register, 63(77): 19842-19850.

VALACHOVIC, Y., TWIEG, B., LEE, C., COBB, R. \&
STARK, D. (2017). Forest stand conditions after Phytophthora ramorum management in northern California: post-treatment observations inform future responses. Forest Phytophthoras 7(1): 54-66.

WEILAND, J.E., SCAGEL, C.F., GRÜNWALD, N.J., DAVIS, E.A., BECK, B.R. \& FIELAND, V.J. (2018). Variation in disease severity caused by Phytophthora cinnamomi, P. plurivora, and Pythium cryptoirregulare on two Rhododendron cultivars. Plant Disease, 102(12): 2560-2570.

YAKABE, L.E., BLOMQUIST, C.L., THOMAS, S.L. \& MACDONALD, J.D. (2009). Identification and frequency of Phytophthora species associated with foliar diseases in California ornamental nurseries. Plant Disease, 93(9): 883-890. 